[Review Paper]

\title{
Subcritical and Supercritical Fluid Technology for Recycling Waste Plastics
}

\author{
Motonobu Goто* \\ Dept. of Chemical Engineering, Nagoya University, Furo-cho, Chikusa-ku, Nagoya 464-8603, JAPAN
}

(Received May 17, 2016)

\begin{abstract}
Supercritical fluid, which is defined as a state of fluid over the critical temperature and pressure, has high potential as a reaction and separation solvent. The development of chemical recycling of waste plastics by decomposition reactions in subcritical and supercritical fluids is reviewed including fundamental investigation and commercialization. Decomposition reactions proceed rapidly and selectively in supercritical fluids compared to conventional processes. Condensation polymerization plastics such as PET and nylon are relatively easily depolymerized to their monomers in supercritical water or alcohols. Crosslinked polymer can be recycled by selective decrosslinking reactions in supercritical fluid without severe decomposition of the backbone chains. Fiber reinforced plastics can also be recycled by depolymerization of the resin component to obtain recovered fibers and monomers. Pilot scale or commercial scale plants using subcritical and supercritical fluids have been developed for plastics recycling.
\end{abstract}

\section{Keywords}

Supercritical fluid, Subcritical fluid, Plastics, Depolymerization, Chemical recycling

\section{Introduction}

Supercritical fluid technology has high potential as an environmentally friendly green process due to the superior properties as chemical reaction media. Recycling technology for waste plastics is very desirable, so much research has investigated the decomposition of plastics using supercritical fluids ${ }^{1) \sim 4)}$. Subcritical and supercritical fluids such as water and alcohol are excellent reaction media for the depolymerization or decomposition of plastics, and polymer decomposition proceeds rapidly and selectively. Recycling technologies have been extensively developed for fundamental research to practical applications. In this article, recycling technology using supercritical fluid as the reaction media is reviewed.

\section{Chemical Recycling of Plastics}

\section{1. Condensation Polymerization Plastics}

Condensation polymers with ether, ester, or acid amide linkages can be depolymerized by hydrolysis. Selective hydrolysis decomposes the polymer into its monomers. Condensation polymers are easily decomposed to monomers by hydrolysis in near-critical water.

Polyethylene terephthalate (PET) was depolymerized to its monomers, terephthalic acid (TPA) and ethylene

DOI: dx.doi.org/10.1627/jpi.59.254

* E-mail: mgoto@nuce.nagoya-u.ac.jp glycol, in subcritical and supercritical water. The TPA yield was close to $100 \%$, but the yield of ethylene glycol was lower because of further decomposition catalyzed by the product TPA. Supercritical methanol was also used to depolymerize PET at 543-573 K, under pressure of $14.7 \mathrm{MPa}$ and reaction time of 5-120 min, which efficiently recovered both monomers, dimethylterephthalate (yield $>99 \%$ ) and ethylene glycol $^{5) \sim 8)}$. The yield of dimethylterephthalate was more than $99 \%$ after 20 min. Analysis of the reaction rate showed that conversion from oligomer to monomer was the rate determining step. Continuous mixture kinetics $^{5), 8)}$ were applied to analyze the decomposition of PET as shown in Fig. 1. PET is degraded by

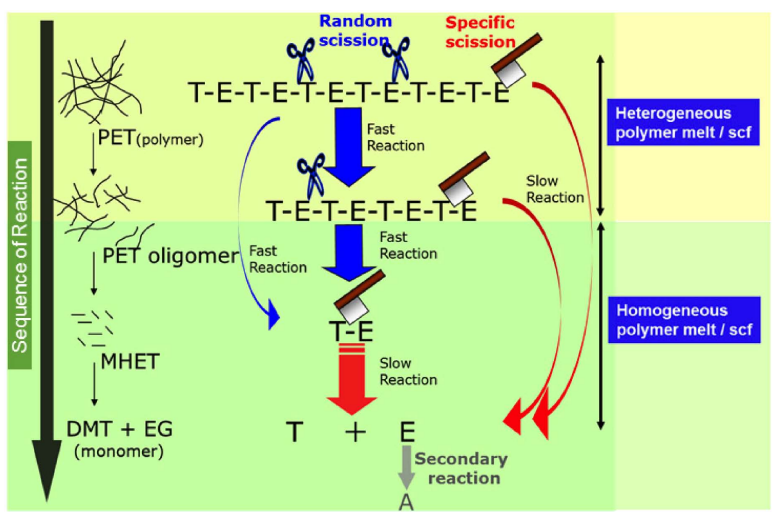

Fig. 1 Depolymerization Mechanism in Supercritical Fluid and the Concept of Continuous Mixture Kinetics 


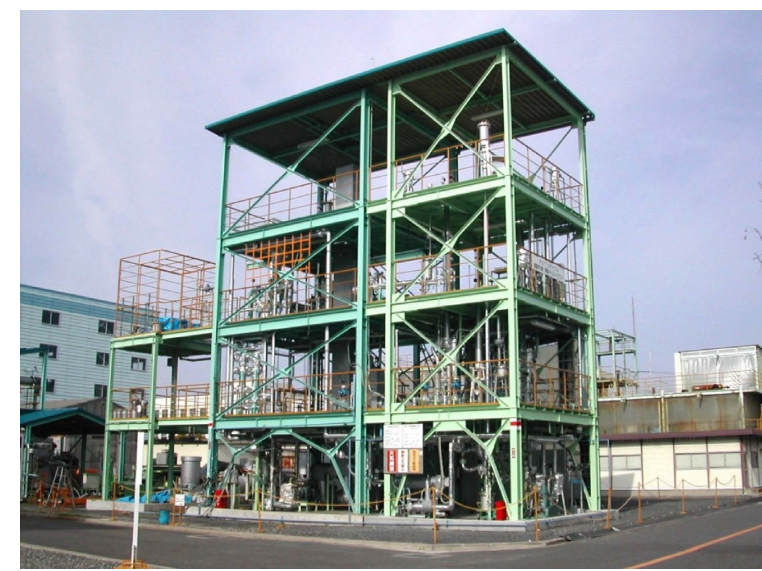

Fig. 2 Pilot Plant for PET Recycling Using Supercritical Methanol

random scission to polymers of smaller molecular weight, which are then continuously depolymerized to yield monomer components by end scission. The estimated molecular weight distribution well simulated the experimental data obtained by size exclusion chromatography. The monomer yield was also calculated and compared as a function of reaction time. Mitsubishi Heavy Industries, Ltd., Japan, has developed a chemical recycling process using supercritical methanol for depolymerizing post-consumer PET bottles on the pilot scale as shown in Fig. $2^{9)}$.

Nylon 6 is a polymer synthesized by ring-opening polymerization of $\varepsilon$-caprolactam, and has been depolymerized by hydrolysis in subcritical and supercritical water ${ }^{10)}$. The liquid phase contained $\varepsilon$-caprolactam and $\varepsilon$-aminocaproic acid with total yield of almost $100 \%$. Therefore, Nylon 6 was decomposed by hydrolysis to $\varepsilon$-aminocaproic acid followed by cyclodehydration to $\varepsilon$-caprolactam or further decomposition to smaller molecules, which indicates that the cyclodehydration reaction proceeds in water near the critical temperature.

Polycarbonates are widely used as commodity plastics and engineering plastics. Several depolymerization processes using alkali catalysts, can decompose polycarbonate synthesized from bisphenol A and phosgene, to produce bisphenol A. Decomposition of polycarbonate in subcritical water at $403-573 \mathrm{~K}$ resulted in the main products of phenol, bisphenol A, and $p$-isopropenylphenol ${ }^{11)}$. The reaction was accelerated by the addition of $\mathrm{Na}_{2} \mathrm{CO}_{3}$.

Polyurethanes are produced by the reaction of polyisocyanate with polyalcohol (polyol). Hydrolysis of polyurethane in water forms the polyol and diamine corresponding to the starting isocyanate ${ }^{12)}$. Decomposition of polyurethane was almost $100 \%$ at temperatures above $543 \mathrm{~K}$. Both polyol and diamine were recovered almost completely. Decomposition of polyurethane foam in subcritical water at $423-623 \mathrm{~K}$

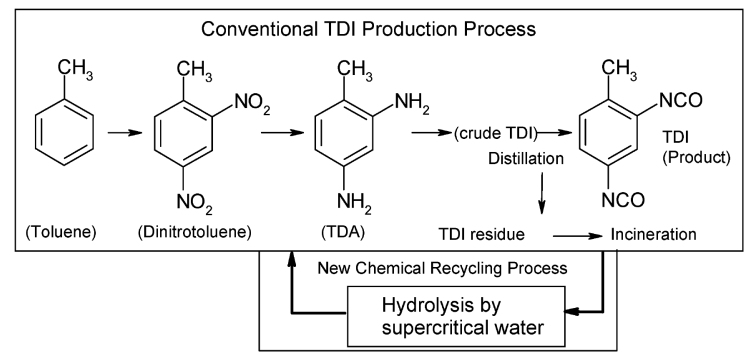

Fig. 3 Concept of Chemical Recycling of TDI to TDA

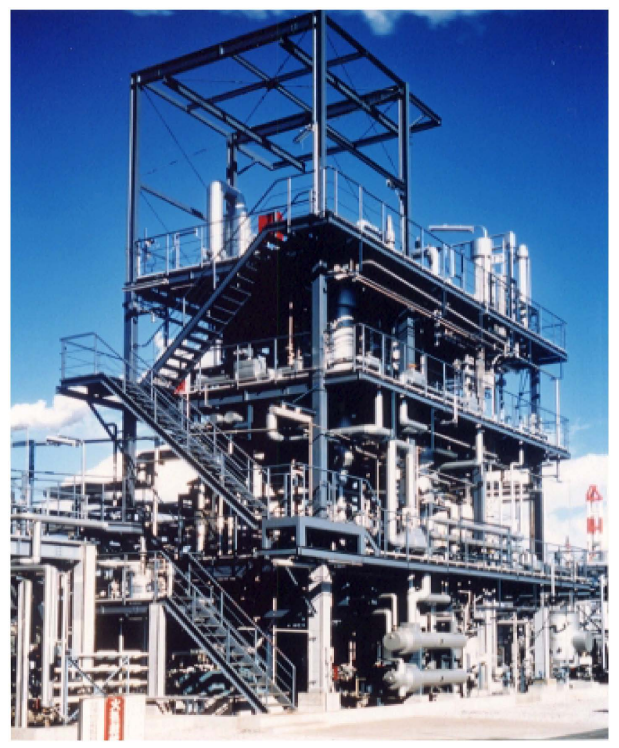

Fig. 4 Commercial Plant for TDI Residue Recycling

formed tolylenediamine (TDA) and polyol with the highest yield of almost $90 \%{ }^{13}$.

Kobe Steel, Ltd. developed a chemical recycling process at Mitsui Takeda Chemicals, Inc. in 1997 by applying noncatalytic hydrolysis in subcritical water. Tolylenediisocyanate (TDI) distillation residue, which is typically incinerated, was successfully converted to TDA as shown in Fig. 3. The commercial plant has been operating since 1998 with a capacity of $10 \mathrm{t} /$ day (Fig. 4). The process consists of a reaction process in subcritical water and a purification process. The recovered TDA was of high quality and more than 99.5\% pure. Expansion of the plant was completed in 2003. Hanhwa Chemical in Korea has commercialized a solid TDI residue recycling process and constructed a plant at Korea Fine Chemical in 2007 with capacity of $20 \mathrm{t} / \mathrm{day}^{3)}$.

\section{2. Addition Polymerization Plastics}

Recycling of thermosetting resins, which are widely used for electronics, is important. Phenol resin has high thermal stability because aromatic units are connected by methylene bonds. Prepolymers of phenol resin were decomposed into their monomers in sub- 
critical and supercritical water ${ }^{14)}$. The total yield of identified products depended on the type of prepolymer; the maximum yield reached $78 \%$ in a reaction at $703 \mathrm{~K}$. The decomposition was accelerated by the addition of $\mathrm{Na}_{2} \mathrm{CO}_{3}$, and the yields of monomers were more than $90 \%$. Decomposition in subcritical and supercritical water was applied to printed circuit boards ${ }^{15)}$ and the liquid phase contained phenol, $o$ cresol, and $p$-cresol.

Flame-retardant plastics (Br-ABS and Br-HIPS) was decomposed in supercritical water in the absence and presence of the alkaline additives $\mathrm{NaOH}$ and $\mathrm{Ca}(\mathrm{OH})_{2}{ }^{16)}$. The main reaction products were oils containing ethylbenzene. The bromine atoms in the plastics were removed into the aqueous phase, and all antimony remained in the solid residues.

Polyethylene is a commodity thermoplastic extensively used in consumer products. Higher yields of shorter chain hydrocarbons, higher 1 -alkene/n-alkane ratio, and higher conversion rates were obtained in supercritical water ${ }^{17)}$. Polyethylene cracking in supercritical water was compared with water-free thermal cracking. Yellow-brown grease was produced from supercritical water cracking ${ }^{18)}$. The yield of oil products was higher and coke production was lower in supercritical water cracking than in thermal cracking.

\section{3. Crosslinked Polyethylene}

Crosslinked polyethylene (XLPE) is a thermosetting resin which is difficult to recycle because of its low fluidity and low moldability due to the crosslinking. XPLE is classified into three types based on the crosslinking: peroxide-crosslinked polyethylene, radiationcrosslinked polyethylene, and silane-crosslinked polyethylene. If only the crosslinking points in XLPE are decomposed, the polymer can be effectively recycled, which does not require decomposition into smaller molecules. Since selective decrosslinking at crosslinking points is difficult in conventional processes, XLPE is usually converted into oil by thermal and catalytic cracking.

Hitachi Cable Ltd. has developed recycling of the insulation of crosslinked polyethylene cable ${ }^{19) \sim 21)}$. The crosslinking element that consists of a siloxane bond in silane-crosslinked polyethylene (silane-XLPE) was selectively decomposed in supercritical alcohol or water as shown in Fig. 5. The crosslinking element was completely decomposed without reduction of the polymer molecular weight by reaction at 573-613 K in methanol. Supercritical methanol achieved selective decomposition at the crosslinking points, whereas supercritical water was less selective. The mechanical and electrical properties of the recycled polyethylene satisfied the requirements for use as cable insulation. A pilot-scale continuous process consisting of a reactor extruder and a degasser extruder was developed.

Decrosslinking of polyethylene in supercritical meth-

\section{Cross-linking bond}

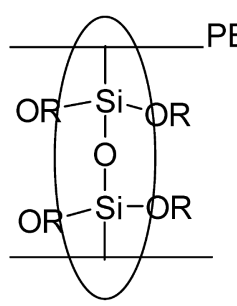

Silane-XLPE
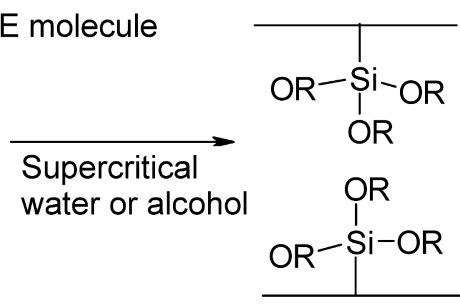

Recycled PE

Fig. 5 Decrosslinking of Silane Crosslinked Polyethylene in Supercritical Fluid

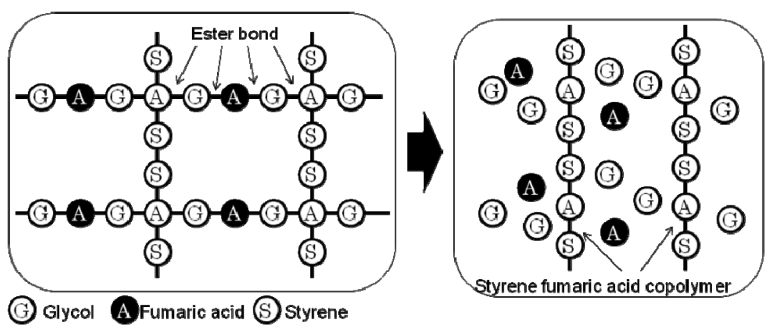

Fig. 6 Concept of FRP Recycling Using Subcritical Water

anol confirmed that the molecular weight of decrosslinked polyethylene was only slightly lower than that of raw polyethylene ${ }^{22)}$.

\section{Materials Recovery from Waste}

Fiber-reinforced plastics (FRPs) have been widely used as a high-strength material in recent years. FRP containing glass fiber (GFRP) is a composite material manufactured by laminating unsaturated polyester resin with glass fiber and filler. FRP containing carbon fiber (CFRP) usually consists of carbon fiber and epoxy resin.

Decomposition of FRP in subcritical and supercritical water resulted in almost complete decomposition at $653 \mathrm{~K}$ in $5 \mathrm{~min}^{23), 24)}$. Decomposition of epoxy resin containing carbon fiber in supercritical water reached $79.3 \mathrm{wt} \%$ at $673 \mathrm{~K}$ and $95 \mathrm{wt} \%$ with alkali catalyst ${ }^{25)}$. The tensile strength of the reclaimed fibers was close to the virgin fibers.

Panasonic Corp. has developed FRP recycling technology since 2002 using hydrolysis in subcritical water $^{26) \sim 28)}$. After subcritical water hydrolysis of FRP, the resin was dissolved into a reaction liquid. The recovered unsaturated polyester components, such as glycols and fumaric acid, were separated from the aqueous reaction liquid and polymerized into polyester with new raw resin materials to produce recycled resin. Styrene-fumaric acid copolymer obtained in the aqueous phase was also separated and can be used as a lowprofile additive for FRP formation (Fig. 6). The recovered inorganic materials can be used as inorganic 


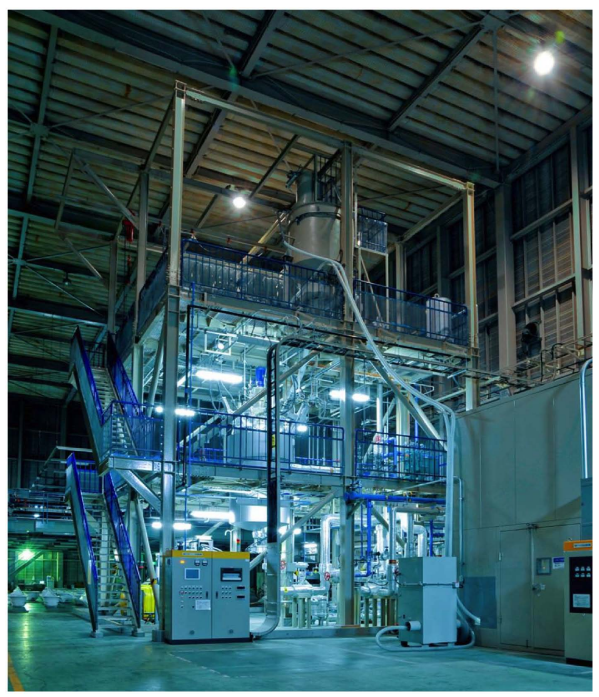

Fig. 7 Pilot Plant for FRP Recycling Using Subcritical Water

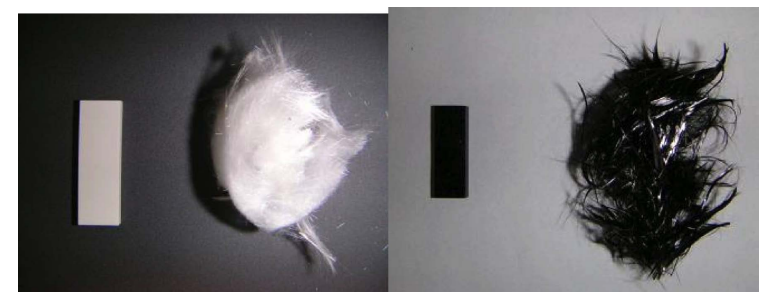

Fig. 8 Recovered Glass Fiber (left) and Carbon Fiber (right) from Treatment in BZA

filler to produce FRP. A pilot plant with a reactor capacity of $2.9 \mathrm{~m}^{3}$ was operated in Tochigi, Japan as shown in Fig. 7.

Hitachi Chemical Co., Ltd. investigated the dissolution process of the resin part of FRP by the "ambient pressure dissolving method" using various solvents with or without catalysts to develop a recycling technology for $\mathrm{FRP}^{29}$ ). The highest conversion was observed using $\mathrm{K}_{3} \mathrm{PO}_{4}$ as the catalyst and diethyleneglycol monomethylether as the solvent. The second highest conversion was observed for benzyl alcohol (BZA).

Operation temperature can be increased under pressures higher than the vapor pressure ${ }^{30), 31)}$. Reactions were carried out with or without a catalyst $\left(\mathrm{K}_{3} \mathrm{PO}_{4}\right)$ in BZA under subcritical states at temperatures ranging from 463 to $623 \mathrm{~K}$ for $1-8 \mathrm{~h}$ in a batch reactor. Conversion of unsaturated polyester (UP) was faster at higher catalyst/solvent molar ratio and was enhanced in the presence of catalyst in subcritical BZA. The glass fibers recovered after FRP treatment in subcritical BZA were relatively long. Carbon fiber was also recovered successfully by treatment in BZA with $\mathrm{K}_{3} \mathrm{PO}_{4}$. Figure 8 shows the fibers recovered by treatment in BZA. Recycling technology using subcritical and supercritical fluid for CFRP has been reviewed ${ }^{4}$.

\section{Conclusions}

The development of chemical recycling of waste plastics by decomposition reactions in subcritical and supercritical fluids is reviewed from fundamental investigations to commercial scale processes. Condensation polymerization plastics are relatively easily depolymerized to their monomers. Crosslinked polymers can be recycled by selective decrosslinking reactions without severe decomposition of the backbone chains. Fiber reinforced plastics can also be recycled by depolymerization of the resin component to yield recovered fibers and monomers.

\section{References}

1) Goto, M., J. Supercrit. Fluids, 47, 500 (2009).

2) Sako, T., Okajima, I., Sugeta, T., Otake, K., Yoda, S., Takebayashi, Y., Kamizawa, C., Polym. J., 32, 178 (2000).

3) Adschiri, T., Lee, Y.-W., Goto, M., Takami, S., Green Chem., 13, 1380 (2011).

4) Morin, C., Loppiner-Serani, A., Cansell, F., Aymonier, C., J. Supercrit. Fluids, 66, 232 (2012).

5) Goto, M., Koyamoto, H., Kodama, A., Hirose, T., AIChE J., 48 (1), 136 (2002).

6) Genta, M., Iwaya, T., Sasaki, M., Goto, M., Hirose, T., Ind. Eng. Chem. Res., 44, 3894 (2005).

7) Genta, M., Iwaya, T., Sasaki, M., Goto, M., Waste Management, 27, 1167 (2007).

8) Genta, M., Goto, M., Sasaki, M., J. Supercrit. Fluids, 52, 266 (2010).

9) Genta, M., Yano, F., Kondo, Y., Matsubara, W., Oomoto, S., Mitsubishi Heavy Industries, Ltd. Technical Review, 40, 1 (2003).

10) Goto, M., Umeda, M., Kodama, A., Hirose, T., Nagaoka, S., Kobunshi Ronbunshu, 58, 548 (2001).

11) Ikeda, A., Katoh, K., Tagaya, H., J. Mater. Sci., 43, 2437 (2007).

12) Nagase, Y., Yamagata, M., Matsuda, T., Naito, T., Kodama, K., Fukuzato, R., Proc. 5th Meeting on Supercritical Fluids, (1998), p. 127.

13) Dai, Z., Hatano, B., Kadokawa, J., Tagaya, H., Polym. Degrad. Stab., 76, 179 (2002).

14) Tagaya, H., Suzuki, Y., Asou, T., Kadokawa, J., Chiba, K., Chem. Lett., 1998, 937 (1998).

15) Goto, M., Kitamura, M., Hirose, T., Shibata, K., "Hydrothermal Reactions and Techniques," World Scientific, New Jersey (2003), p. 201.

16) Onwudili, J. A., Williams, P. T., J. Supercrit. Fluids, 49, 356 (2009).

17) Watanabe, M., Adschiri, T., Arai, K., Kobunshi Ronbunshu, 58, 631 (2001).

18) Moriya, T., Enomoto, H., Polym. Degrad. Stab., 65, 373 (1999).

19) Goto, T., Yamazaki, T., Hitachi Cable Rev., 23, 24 (2004).

20) Goto, T., Ashihara, S., Yamazaki, T., Watanabe, K., IEEJ Trans., PE 126, 400 (2006).

21) Goto, T., Yamazaki, T., Sugeta, T., Okajima, I., Sako, T., J. Appl. Polym. Sci., 109, 144 (2008).

22) Hong, S. M., Cho, H. K., Koo, C. M., Lee, J. H., Park, W. Y., Lee, H. S., Lee, Y. W., Korean Chem. Eng. Res., 46, 63 (2008).

23) Sugeta, T., Nagaoka, S., Otake, K., Sako, T., Kobunshi Ronbunshu, 58, 557 (2001).

24) Okajima, I., Yamada, K., Sugeta, T., Sako, T., Kagaku Kogaku Ronbunshu, 28, 553 (2002).

25) Pinero-Hernanz, R., Dodds, C., Hyde, J., Garcia-Serna, J., 
Poliakoff, M., Lester, E., Cocero, M. J., Kingman, S., Pickering, S., Wong, K. H., Composites, Part A, 39, 454 (2008).

26) Nakagawa, T., JEC Composites Magazine, March-April, 40 (2008).

27) Nakagawa, T., Goto, M., Polym. Degrad. Stab., 115, 16 (2015).

28) Nakagawa, T., Goto, M., Engineering J., 19, (5), 1 (2015).

29) Fukuzawa, H., Shibata, K., Izawa, H., Proc. 13th Conf. Japan
Soc. Waste Management Experts, (2002), p. 428.

30) Iwaya, T., Tokuno, S., Sasaki, M., Goto, M., J. Mater. Sci., 43, 2452 (2008).

31) Ibarra, R. M., Sasaki, M., Goto, M., Quitain, A. T., Montes, S. M. G., Aguilar-Garib, J. A., J. Mater Cycles Waste Manag., 17, 369 (2015).

\title{
要旨
}

\section{亜臨界・超臨界流体を用いた廃プラスチックのリサイクル技術}

\author{
後藤 元信 \\ 名古屋大学大学院工学研究科, 464-8603 名古屋市千種区不老町
}

超臨界流体は臨界温度と臨界圧力を超えた状態であり, 反応 や分離溶媒として注目されている。亜臨界・超臨界流体を用い た分解反応による廃プラスチックの化学リサイクル技術につい て基礎から商用プラントに至るまで総括する。従来プロセスに 比べて超臨界流体中では分解反応が迅速かつ選択的に進行す る。PET やナイロンなどの縮重合系プラスチックは超臨界水や
超臨界アルコール中で比較的容易にモノマーに解重合される。 架橋高分子は主鎖の過度の分解を伴わずに選択的脱架橋化反応 によりリサイクルできる。繊維強化プラスチックは樹脂部分を 解重合することにより繊維や化学原料として回収できる。廃プ ラスチックのリサイクルのために亜臨界・超臨界流体を用いた パイロット規模や商用規模のプラントが開発されている。 